ROCZNIKI HUMANISTYYCZNE

Tom LXVII, zeszyt 6 - 2019

DOI: http://dx.doi.org/10.18290/rh.2019.67.6-9

\title{
STRATEGIE NOMINACYJNE I NARRACYJNE JAKO ŚWIADECTWO ZACHOWAŃ ETYCZNYCH W DYSKURSIE ZWIAZZANYM Z ORGANIZOWANIEM EDUKACJI OSÓB Z NIEPEŁNOSPRAWNOŚCIAMI
}

Etyczne zachowanie językowe w szczególny sposób wiązane jest z pewnymi sferami życia człowieka, w których konieczny jest, oprócz zwykłej grzeczności językowej, normatyw moralny obligujący mówiącego do delikatności i wrażliwości wobec drugiego człowieka, zwłaszcza w jakimś sensie słabszego. Według Jadwigi Puzyniny i Anny Pajdzińskiej realizuje się to w postulacie mówienia tak, aby partnerzy komunikacji czuli się bezpiecznie i mieli świadomość akceptacji, by nie krzywdzić słowem wrogim, poniżającym czy raniącym $^{1}$. Jest to szczególnie widoczne $\mathrm{w}$ przypadkach niedomagań zdrowotnych, których opis w języku obciążony jest z jednej strony tabu (pewne choroby uznawane są za szczególnie wstydliwe), z drugiej poddany szczególnej uwadze w zakresie konstruowania wypowiedzi z punktu widzenia etykiety językowej, w trosce o takt wobec osób chorych, obciążonych dysfunkcjami.

Wynika to z przekonania, że przekraczanie reguł etyki ma większą szkodliwość społeczną niż przekraczanie normy grzecznościowej², choć zachowania

Dr Dorota SzAgun - adiunkt Zakładu Historii i Pragmatyki Języka Polskiego, Instytut Filologii Polskiej Uniwersytetu Zielonogórskiego; adres do korespondencji: al. Wojska Polskiego 69, 65-001 Zielona Góra; e-mail: d.szagun@ifp.uz.zgora.pl

${ }^{1}$ Zob. J. PUZYNINA, A. PAJDZIŃSKA, Etyka stowa, w: O zagrożeniach i bogactwie polszczyzny, red. J. Miodek, Wrocław: Towarzystwo Przyjaciół Polonistyki Wrocławskiej 1996, s. 42.

2 Por. M. Bugajski, Etyka, etykieta, kultura jezzka, „Poznańskie Spotkania Językoznawcze" 2012, t. 24, s. 13; M. MARCJANIK, Miejsce etykiety językowej wśród wartości. Uwagi 
językowe określane jako etyczne często postrzega się właśnie w świetle Grice'owskiej zasady kooperacji z maksymami szczegółowymi: ilości, jakości, a zwłaszcza relewancji i sposobu. W tym sensie możemy mówić o etyce słowa czy szerzej - etyce dyskursu publicznego jako pragmatycznym aspekcie komunikacji społecznej. Elementy językowe świadczące o etyce językowej czy nieetycznych zachowaniach językowych stoją na granicy zainteresowań językoznawczych, należąc de facto do sfery kontaktu językowego, sposobu używania języka, i są - jak pisał Zenon Klemensiewicz ${ }^{3}$ - elementem społecznego obcowania. Zainteresowaniem językoznawczym można zatem objąć sposoby etyzacji języka, czyli dobór elementów językowych i formułowanie wypowiedzi ze szczególnym uwzględnieniem kształtowania relacji nadawczoodbiorczych z pobudek etycznych. Potrzeba dostosowywania języka do wymogów etycznych jest domeną dyskursu publicznego, dążącego do poprawności politycznej, czyli - w najogólniejszym ujęciu - unikania w dyskursie publicznym określeń mogących stygmatyzować, dyskryminować lub wykluczać pewne grupy społeczne ${ }^{4}$.

Niniejszy artykuł podejmuje próbę opisu elementów językowych, w ich aspekcie etycznym, obecnych w dyskursie publicznym na temat indywidualnej edukacji uczniów niepełnosprawnych. Dyskurs ten obejmuje wypowiedzi medialne, w których skład wchodzą: przede wszystkim petycja Moniki Mamulskiej ${ }^{5}$ inicjująca zainteresowanie uczniami $\mathrm{z}$ niepełnosprawnościami w świetle zmian w przepisach MEN z 9 i 28 sierpnia $2017^{6}$ roku oraz liczne artykuły prasowe, informacje na portalach internetowych rozgłośni radiowych, a także strony zajmujące się działalnością charytatywną i społeczną, które

ogólne, (Język a kultura, t. 3: Wartości w języku i tekście, red. J. Puzynina, J. Anusiewicz), Wrocław: Uniwersytet Wrocławski 1991, s. 64.

${ }^{3}$ Zob. Z. Klemensiewicz, Higiena językowego obcowania, ,Język Polski” 45(1965), z. 1, s. $1-8$.

${ }^{4}$ Zob. R. ZimnY, O sposobach uzasadniania jezykowych zachowań nieetykietalnych, „Poznańskie Spotkania Językoznawcze” 2012, t. 24, s. 173-192.

${ }^{5}$ Petycja pojawiła się w lutym 2018 roku na stronie https:// naszademokracja.pl/petitions/pozwolcie-dzieciom-niepelnosprawnym-z-nauczaniem-indywidualnym-uczyc-sie-w-szkole-1. Do 1 października 2018 roku pod petycją podpisało się ponad 100000 osób.

${ }^{6}$ Mowa tu o dwóch rozporządzeniach: Rozporządzenie Ministra Edukacji Narodowej z dnia 9 sierpnia 2017 r. w sprawie warunków organizowania kształcenia, wychowania i opieki dla dzieci i młodzieży niepełnosprawnych, niedostosowanych społecznie i zagrożonych niedostosowaniem społecznym; Rozporządzenie Ministra Edukacji Narodowej z dnia 28 sierpnia 2017 r. zmieniające rozporządzenie w sprawie zasad udzielania i organizacji pomocy psychologiczno-pedagogicznej w publicznych przedszkolach, szkołach i placówkach. 
petycję tę rekomendowały ${ }^{7}$. Jako podstawę dyskursu przyjmujemy także opinie strony rządowej, reprezentowanej przez MEN. Materiał stanowi pięć komentarzy/odpowiedzi MEN do artykułów prasowych podpisanych przez Rzecznika Prasowego MEN Annę Ostrowską oraz trzy artykuły z aktualności zamieszczone na stronach MEN.

Debata dotycząca edukacji dzieci i młodzieży z niepełnosprawnościami prowadzona między Ministerstwem Edukacji Narodowej a rodzicami reprezentowanymi przez media jest wyraźnie niesymetryczna, tj. z przewaga głosów medialnych i sporadycznych odpowiedzi MEN na opublikowane artykuły prasowe oraz jedną konferencją prasową z 10 września 2017 roku. Przyjmujemy, że brak symetrii ilościowej pomiędzy materiałami prasowymi a reakcjami ministerialnymi, postrzeganymi jako pewna zachowawczość strony rządowej $\mathrm{w}$ dialogu społecznym, jest jedną $\mathrm{z}$ charakterystycznych cech tego dyskursu.

W obrębie analizowanych tekstów interesują nas przede wszystkim strategie nominacyjne osób z niepełnosprawnościami i ich opiekunów oraz strategie narracyjne związane $\mathrm{z}$ osobami z niepełnosprawnościami, rozpięte dwubiegunowo pomiędzy leksemami właczenie - wykluczenie, w narracji określającej możliwości - obowiazki uczestników dyskursu, do których należą: MEN, szkoła i reprezentujący ją dyrektor oraz nauczyciele, a także rodzice i dzieci.

\section{STRATEGIE NOMINACYJNE OSÓB Z NIEPEŁNOSPRAWNOŚCIAMI JAKO POTRZEBA JEZZYKA ETYCZNEGO W DYSKURSIE PUBLICZNYM}

Strategie nominacyjne przez sam fakt odniesienia aktu komunikacji do osoby, tak w wymiarze etycznym, jak i etykietalnym odnoszą się do metafory twarzy Ervinga Goffmana. Uzyskuje się to poprzez stosowanie rozmaitych grzecznościowych strategii językowych powiązanych z obyczajem społecznym, przestrzeganiem norm etycznych ${ }^{8}$. W zakresie nominacji osób z niepełnosprawnościami do głównych strategii grzecznościowych, a zarazem etycznych należy stosowanie form eufemistycznych, nazywających chorobę, upośledzenie lub dysfunkcję. Zastosowana w tytule niniejszego tekstu struktura wyrażenia osoby $z$ niepetnosprawnościami jest formą obowiązującą w dokumentach z zakresu orzecznictwa prawnego i innych dokumentach urzędo-

\footnotetext{
${ }^{7}$ Podstawa materiałowa znajduje się w wykazie literatury.

${ }^{8}$ Por. M. MARCJANIK, Miejsce etykiety jezzykowej wśród wartości, s. 62-63.
} 
wych. Z historycznego punktu widzenia są to jednak konstrukcje dość nowe. Nominacje osób z niepełnosprawnościami oparte są ściśle na tworzeniu wyrażeń z przymiotnikami atrybutywnymi, które w ciągu dziejów języka polskiego podlegały zmianom ilościowym i jakościowym. W wyniku zmian mentalnych narodowej wspólnoty komunikatywnej w dyskursie publicznym niemalże nie zaświadczymy już leksemów: ślepy, chromy, głuchy (choć nadal, z racji ciągłości historycznej, na mocy tradycji mamy wszak Polski Związek Głuchych), obecnych w SJPD ${ }^{9}$, które uznawane są za przymiotniki absolutnej jakości i oceny, ale współcześnie uznawane za dosadne, negatywnie waloryzujące nosicieli tychże cech, funkcjonujące czasem jako nazwy-etykietki ${ }^{10} . \mathrm{Z}$ tych względów, poza językiem potocznym lub literackim zorientowanymi na przekazywanie emocji, określenia te nie pojawiają się w dyskursie publicznym, ze względu na postrzeganie ich jako stygmatyzujące, a więc krzywdzące i nieetyczne. Kolejna grupa określeń różnego rodzaju dysfunkcji, która powstała w polszczyźnie jako efekt eufemizacji nazw osób z niepełnosprawnościami, a więc stopniowej etyzacji pojęć, to przymiotniki negatywne, wyrazy powstałe poprzez językowy zabieg zaprzeczenia: niewidomy, niewidzacy (niedowidzacy), niestyszacy (niedostyszacy). W SJPD poświadczamy leksemy: niewidomy w znaczeniu 'nie mogący widzieć, z powodu wady wzroku, ślepy', niewidzacy (z kwalifikatorem rzadki), ale nie znajdujemy jeszcze zleksykalizowanej formy niestyszacy, jedynie w parafrazie leksemu głuchy pojawiają się wyrażenia z imiesłowem nie styszacy, źle słyszacy: SJPD - 'człowiek, zwierzę o nie funkcjonującym narządzie słuchu; całkowicie lub częściowo pozbawiony zmysłu słuchu; nie słyszący, źle słyszący'. Wynika to z jednej strony z potrzeby etyzacji języka, która przejawia się w stałym osłabianiu elementów wyrazistych, oceniających, z drugiej - z dążenia do pewnej precyzji nazewniczej.

Usuwanie z dyskursu publicznego elementów ślepy, głuchy, chromy, zastąpionych przymiotnikami negatywnymi, będącymi jednocześnie eufemistycznymi synonimami niewidomy/niewidzacy, niestyszacy, niepetnosprawny (ten ostatni leksem podlega daleko idącemu uogólnieniu, obejmując wszystkie dysfunkcje organizmu) jest obrazem zmian zachodzacych w świadomości wobec osób z niepełnosprawnościami, ale też zmian świadomości społecznej w ogóle. Wcześniej dominująca i aprobowana społecznie była tzw. norma,

\footnotetext{
${ }^{9}$ Stownik języka polskiego, red. W. Doroszewski, t. 1-11, Warszawa 1958-1969 [SJPD].

${ }_{10}$ Zob. M. KoCHAN, „Przyklejanie etykietek”, czyli o negatywnym określaniu przeciwnika, (Język a kultura, t. 11: Język polityki a wspótczesna kultura polityczna, red. J. Anusiewicz, B. Siciński), Wrocław: Towarzystwo Polonistyki Wrocławskiej 1994, s. 86; J. BRALCZYK, O języku polskiej propagandy politycznej lat siedemdziesiatych, Warszawa: Wydawnictwo Trio 2007.
} 
pewna standardowość, a odstępstwa rozumiane jako zjawisko niepożądane. Dziś w świetle rozwiniętej myśli społecznej i haseł humanistycznych dowartościowuje się także inność.

Określenia typu niewidzacy podlegają w języku derywacji syntaktycznej, czyli substantywizacji. Jako rzeczowniki, nazwy atrybutywne obrazują osobę wyłącznie przez pryzmat choroby czy dysfunkcji (np. Niewidomy może..., Każdy niestyszacy ma prawo...), dotyczy to także określenia o dużym stopniu ogólności - niepetnosprawny. Spośród nich na podstawie badanych tekstów dyskursu publicznego zaświadczamy jedynie kilka leksemów: niepetnosprawny (być może ze względu na swoją dużą ogólność, brak powiązania z konkretnym rodzajem dysfunkcji, choroby), niewidomy i niestyszacy (czasem też stabostyszacy) oraz upośledzony. Poza tymi określeniami wśród strategii nominacyjnych omawianych tekstów wyraźnie dominują rozbudowane wyrażenia, zwykle z przydawką w postaci wyrażenia przyimkowego typu: $z$ autyzmem, $z$ niepetnosprawnościami itp. Sa to wyrażenia o charakterze peryfrastycznym, osłabiającym cechę niepełnosprawności, mająca określać podmiot. Za tym idzie też silna szablonowość języka i eliminowanie prostych elementów językowych obecnych w polszczyźnie, jako częstszych w potocznej odmianie stylistycznej, a kontekstowo posiadających konotacje negatywne. Zjawisko to jest o tyle interesujące, że stanowi tendencję przeciwną do skracania i upraszczania form grzecznościowych $\mathrm{w}$ komunikacji codziennej ${ }^{11}$, zatem wiąże się z pewną nieekonomicznością systemu. Spośród wcześniej wymienionych nazw prostych, leksemy niewidomy i niestyszacy pozostają niezmienne ze względów gramatycznych, nie mają bowiem odpowiedników rzeczownikowych o tych samych podstawach słowotwórczych (jak np. niepetnosprawny - niepetnosprawność), a przez to nie tworzą konstrukcji peryfrastycznych (typu: niepetnosprawny - osoba z niepetnosprawnościa / niepetnosprawnościami). Nazwy atrybutywne niewidomy i niestyszacy łączą się jedynie z nacechowanymi rzeczownikami ślepota, głuchota. Jedynie forma pochodna niedostyszacy tworzy parę z neutralnym rzeczownikiem niedostuch i poświadcza konstrukcje peryfrastyczną: osoba $z$ niedostuchem.

We współczesnym dyskursie związanym z organizowaniem edukacji osób z niepełnosprawnościami dominują zatem następujące złożone konstrukcje nazewnicze: uczeń $z$ niepetnosprawnościami (x9); uczeń z niepetnosprawnościa (x9); osoba z niepetnosprawnościami, dziecko z niepełnosprawnościami

\footnotetext{
${ }^{11}$ Pisali o tym: K. OżÓG, A. CHARCIAREK, Najnowsze zmiany zwrotów grzecznościowych w kręgu stowiańskim, „Poznańskie Spotkania Językoznawcze” 2012, t. 24, s. 119-133.
} 
(x8); dziecko z niepetnosprawnościa; uczeń ze specjalnymi potrzebami (x3); dzieci i młodziez ze specjalnymi potrzebami edukacyjnymi (x2); uczeń ze specjalnymi potrzebami edukacyjnymi (x18); uczeń ze SPE; dziecko ze specjalnymi potrzebami edukacyjnymi (x6); dziecko/ uczeń z różnymi potrzebami; uczeń, który ma problem z funkcjonowaniem szkolnym; uczeń, który ma problem $z$ funkcjonowaniem $w$ szkole; uczeń, którzy ma z różnych powodów problemy szkolne; uczeń z orzeczeniem o potrzebie ksztatcenia specjalnego; uczeń posiadajacy orzeczenie o potrzebie ksztatcenia specjalnego (x2); uczeń $z$ autyzmem $(\mathrm{x} 2)$; uczeń $z$ niepetnosprawnościami sprzęzonymi; uczeń z niepetnosprawnościa intelektualna; uczeń z afazja; uczeń z niepetnosprawnościa intelektualna $w$ stopniu umiarkowanym lub znacznym (x2); uczeń majacy trudności w uczeniu się i/lub komunikowaniu się (x2); uczniowie po wypadkach, $z$ urazami, z cięzkimi chorobami, uczniowie obejmowani ksztatceniem na podstawie orzeczenia o potrzebie ksztatcenia specjalnego. Konstrukcje te polegają na składniowym łączeniu wyrazów, w wyniku którego powstaje skupienie składniowe, derywat składniowy, którego cechą, niezależnie od długości, jest odniesienie do jednego desygnatu ${ }^{12}$. Chociaż wyraźnie widnieją obok siebie konstrukcje w liczbie pojedynczej i mnogiej typu: $z$ niepetnosprawnościa, z niepetnosprawnościami, funkcjonują one synonimicznie, zdaje się, że liczba mnoga nie konotuje wcale znaczenia o wielu dysfunkcjach. Oprócz tych rozbudowanych struktur syntaktycznych, wyjątkowo w dyskursie urzędowym pojawiają się rzeczowniki nazywające konkretne jednostki chorób lub bardziej doprecyzowane dysfunkcje, choć zwykle są one stosowane jako egzemplum wcześniej wymienionych ogólnych niepełnosprawności. Są to: autyzm (uczeń z autyzmem), zespót Aspergera (uczeń z zespotem Aspergera), niepetnosprawność ruchowa (uczeń z niepetnosprawnościa ruchowa), choroba nowotworowa, pisze się także o uczniu niewidomym $i$ słabowidzacym oraz о исzniu niestyszacym (x2).

Oczywiście tego typu zabiegi językowe mogą także być skutkiem zgodności prawnej, gdyż w prawie oświatowym mianem ucznia z niepełnosprawnościami określa się dziecko, które wymaga specjalnej organizacji nauki i metod pracy. I takie widzenie przyczynia się do funkcjonowania w języku peryfraz typu: dzieci/młodzież ze specjalnymi potrzebami edukacyjnymi, uczniowie ze specjalnymi potrzebami, uczniowie z niepetnosprawnościami, do tej samej grupy należą omowne określenia typu: uczniowie z niedostosowaniem

\footnotetext{
${ }^{12}$ Zob. derywat składniowy, skupienie składniowe L.A. JANKOWIAK, Stownictwo medyczne Stefana Falimirza, t. 1: Poczatki polskiej renesansowej terminologii medycznej, Warszawa: Slawistyczny Ośrodek Wydawniczy 2005, s. 103.
} 
społecznym, uczniowie zagrożeni niedostosowaniem społecznym. Współcześnie wyraźnie widać tendencje zastępowania w dokumentach prawnych, urzędowych przydawek określających typu niepetnosprawny, niedostosowany, niestyszacy itp. formułami typu uczeń z... Wydaje się, że zabiegi te mogą wynikać z potrzeb etycznych wyrażanych przez język, z których podstawową jest ucieczka przed stygmatyzacją dzieci i młodzieży, jakoby niepełnosprawność, niedostosowanie, niedosłuch itp. miały całkowicie definiować ich jako osoby. Ponadto jest to próba precyzji językowej, w ten sposób z jednej strony podkreśla się stałą przynależność dysfunkcji, która nie jest chorobą, a zatem nie można jej wyleczyć i nie ustąpi w czasie, z drugiej - przez zastąpienie przymiotników atrybutywnych w funkcji modyfikującej (uczeń niepetnosprawny) konstrukcjami predykatywnymi uczeń z... w sensie: uczeń, który ma np. niepetnosprawność, niepetnosprawności, unika się utożsamienia osoby z niepełnosprawnością.

Rozbudowane konstrukcje językowe są też niezaprzeczalną cechą stylu urzędowo-kancelaryjnego, ich obecność w tekstach ministerialnych odpowiada kryteriom gatunkowym i stylowym tekstów. Dotyczy to tak rozporządzeń, jak i komunikatów MEN, czy listów Minister Edukacji Narodowej kierowanych do organów podległych. Podczas analizy tychże tekstów pod względem etycznych aspektów użytego języka rozbudowane konstrukcje nazywające dzieci i młodzież pełnią funkcję peryfraz o funkcji eufemizacyjnej (zgodnie z realizacją Cycerońskiej retorycznej zasady verecundia 'powściągliwości, dyskrecji'), są próbą ucieczki przed stygmatyzacją wiązaną z używaniem wyrazistych atrybutywnych połączeń językowych opartych na przydawce przymiotnej typu: niepetnosprawny. Wydaje się jednak, że dążenie do poprawności politycznej w jakiejś mierze prowadzi i tak do pułapki dehumanizacyjnej praktyki nazywania osób przez pryzmat jednostki chorobowej, czego wyrazistym przykładem jest chociażby konstrukcja (zgodna skądinąd z ogólną tendencją do tworzenia i stosowania skrótowców): uczniowie ze SPE (w rozumieniu: uczniowie ze specjalnymi potrzebami edukacyjnymi). Konstrukcja uczniowie ze SPE tworzy analogię np. do konstrukcji uczniowie z ADHD i innych stosowanych powszechnie skrótów medycznych wiązanych z rozpoznaniem zaburzenia czy choroby i przypisaniem jej typu do podmiotu (wymieńmy tu chociażby SMA, ChAD, HPV itp.).

Wyjątkowo w tekstach urzędowych pojawiają się formy prostsze, które poświadczyliśmy głównie w tekście z aktualności na stronach MEN: Dziecko ze specjalnymi potrzebami edukacyjnymi $w$ szkołach $z$ rówieśnikami (jest to zapis wystapienia wiceminister Marzeny Machałek z konferencji prasowej 10.09.2012 roku). Tekst ten prymarnie miał postać mówioną, dopiero wtórnie 
- pisaną, co z pewnością wpłynęło na zastosowanie form prostszych, bardziej ekonomicznych językowo i bliższych polszczyźnie potocznej. Zestawiając teksty urzędowe $\mathrm{z}$ materiałami prasowymi, wyraźnie widzimy, że w tych drugich obecne są zarówno nazewnicze konstrukcje złożone: uczniowie/dzieci $z$ orzeczeniem o potrzebie ksztatcenia specjalnego, nasze dzieci z niepetnosprawnościami, dzieci z niepetnosprawnościami, uczniowie zniepetnosprawnościa, dzieci potrzebujace specjalnego wsparcia, dziecko ze spektrum autyzmu, jak i proste wyrażenia. W artykułach prasowych, notatkach informacyjnych witryn internetowych dwukrotnie częściej jednak niż w tekstach urzędowych występują formy krótkie. Są to głównie wyrażenia: dziecko niepełnosprawne, uczeń niepetnosprawny, osoba niepetnosprawna. Ponadto publicystyka, podejmując się reprezentowania postulatów rodziców dzieci niepełnosprawnych, częściej przyjmuje perspektywę włączającą lub po prostu punkt widzenia rodziców przez wyrażenia: nasze dzieci, wszystkie dzieci, każde dziecko, każdy uczeń, oraz leksemy: dziecko, uczeń, syn, a także nazwy zindywidualizowane odnoszące się właśnie do konkretnych przypadków: Janek, niepetnosprawny Tomek, Tomek, Wojtek.

Obecność rozbudowanych form typowych dla języka urzędowego w prasie jest pochodna potrzeby ścisłości nazewniczej środowiska osób z niepełnosprawnościami (co jest ściśle związane z potrzebą wykształcenia etycznego sposobu mówienia o niepełnosprawności), a także dążność do korelacji z językiem urzędowym i medycznym, do którego zapisów się odnoszą. Dziennikarze wielokrotnie powołują się na zapisy ministerialne, cytując wprost sformułowania urzędowe. $Z$ kolei formy proste, opatrywane nazwami własnymi lub przydawkami dzierżawczymi inkluzywnymi: nasze, moje wprowadzają pierwiastek emocjonalny do wypowiedzi prasowych, mający wywołać odpowiednio empatyczne reakcje czytelników na tekst, a pośrednio stanowić formę nacisku społecznego, ale są też wyrazem reprezentowania środowiska osób niepełnosprawnych.

\section{STRATEGIE NARRACYJNE}

JAKO ŚWIADECTWO ZACHOWAŃ ETYCZNYCH W DYSKURSIE PUBLICZNYM O KSZTAŁCENIU OSÓB Z NIEPEŁNOSPRAWNOŚCIAMI

W swych rozważaniach na temat etyki ludzkiej komunikacji Jadwiga Puzynina podkreślała, że dotyczy ona „wszystkich uczestników aktu mowy: nadawcy, ewentualnych jego współpracowników, pośredników oraz odbiorcy 
komunikatu"13. Kształtowanie i wyrażanie w dyskursie publicznym relacji między uczestnikami komunikacji, określanie stosunku jednych do drugich może mieć znamiona zachowań nieetycznych. Wykluczenie lub włączenie postrzegane jest $\mathrm{w}$ analizowanych tekstach sporu o edukację osób $\mathrm{z}$ niepełnosprawnościami w wymiarze etycznym - jako wykluczenie społeczne, a zwłaszcza wyłączenie niepełnosprawnych z relacji rówieśniczych.

$\mathrm{Z}$ tego powodu, choć dyskurs w sensie językowym wprowadza leksykę z pola semantycznego niepełnosprawności, zawsze postrzega ją także z punktu widzenia pełnosprawności. Wynika to $\mathrm{z}$ faktu, że przymiotniki atrybutywne niestopniowalne są względem siebie komplementarne, wpisując się w dychotomiczne postrzeganie rzeczywistości ${ }^{14}$. Wyraża się to w konstrukcjach typu: Uczeń z niepetnosprawnościami ma takie samo prawo do edukacji $w$ szkole jak uczeń petnosprawny. W kontekście stosowania rozbudowanych form peryfrastycznych widać, że dotyczą one tylko jednej strony rzeczywistości. Potrzeba języka etycznego wykształca szereg konstrukcji typu: uczeń z niepełnosprawnościami, gdy po drugiej stronie znajdujemy proste wyrażenia: uczeń petnosprawny lub po prostu uczeń, dziecko, rówieśnik. Wiele wyrazów obecnych w dokumentach urzędowych tworzy w dyskursie społecznym pary opozycyjne. Poprzez nazywanie pewnej określonej, i w jakimś sensie odrębnej, rzeczywistości liczne wyrazy uzyskują swą waloryzację w szerszym kontekście. Jeśli w najnowszych pismach i dokumentach MEN pojawia się edukacja wtaczajaca, to z oczywistych względów postrzegamy ją na tle zjawiska wykluczenia społecznego, przeciwko któremu wielokrotnie protestowali rodzice dzieci niepełnosprawnych (uwzględnijmy tu chociażby ostatni protest z sierpnia 2018 roku: „Pozwólmy wszystkim dzieciom chodzić do szkoły”). Zasadniczo sama petycja i część tekstów publicystycznych ma charakter postulatywny: Pozwólcie dzieciom niepetnosprawnym na nauke $w$ szkole (rmf24.pl; polsatnews.pl; kobieta.onet.pl; newsweek.pl); w jednym przypadku postulat dotyczy także potrzeb rodziców dzieci niepełnosprawnych: Pozwólcie dzieciom z niepetnosprawnościami uczyć się $w$ szkole, a ich rodzicom i opiekunom kontynuować w tym czasie prace (wysokieobcasy.pl). Często jednak w publicystyce zaświadczamy „podgrzewanie” emocji za pomocą retoryki apelującej do uczuć, jak to ma miejsce w nagłówku: Czy 9 tys. uczniów z niepetnosprawnościa zostanie wykluczonych ze szkót w Warszawie? (wieści24.pl);

13 J. PUZYNINA. O warunkach udanej komunikacji językowej, w: Etyka międzyludzkiej komunikacji, red. J. Puzynina, Warszawa: Wydawnictwo Semper 1993, s. 21.

${ }^{14}$ Por. E. WojciechowsKi, O logice przymiotników, „Kwartalnik Filozoficzny” 43(2015), z. 1 , s. 25 
ale także w wezwaniu: Podpisz petycje o niewykluczaniu (mimowszystko.pl) i w zakresie emocjonalnych sformułowań typu: rodzice niepetnosprawnych dzieci bija na alarm; Rodzice chca zmiany nieludzkich przepisów. Pojawienie się w dokumentach MEN słowa kluczowego wtaczajacy: edukacja właczajaca (x6), Liderzy Edukacji Właczajacej, Europejska Agencja ds. Specjalnych Potrzeb i Edukacji Wtaczajacej, Centrum Wsparcia Edukacji Właczajacej z towarzyszącym zwrotem uczeń wraca do szkoty (w artykułach Edukacja wtaczajaca - odpowiedzi MEN na najważniejsze pytania Organizacja ksztatcenia uczniów ze specjalnymi potrzebami edukacyjnymi - działania MEN skierowane do dzieci i młodzieży z niepetnosprawnościami - obydwa z 23.07.2018 roku), jest zatem wyraźną reakcją na medialnie uruchomiony kontekst wykluczenia dzieci niepełnosprawnych z nauczania na terenie szkoły.

Wykluczenie sygnalizowane jest w tekście, oprócz podstawowego i najczęściej używanego czasownika wykluczać, przez strategie narracyjne z często dosadnymi, obrazowymi czasownikami lub rzeczownikami odsłownymi, typu: wymusza [...] zamknięcie dzieci w czterech ścianach, odizolowanie ich od rówieśników, zabrana możliwość nauki wśród rówieśników, dzieci potrzebujace specjalnego wsparcia sa wypychane ze szkót $i$ zamykane $w$ domach, ma siedzieć $w$ domu, pisze się o społecznej izolacji i o barierach $w$ środowisku. Zbiera to sentencjonalna pointa jednego z artykułów: zamiast integracji jest segregacja. Oczywiście obraz wypychania uczniów niepełnosprawnych ze szkoły jest emocjonalną konstrukcją retoryczną i w pewnym sensie nadużyciem, mającym na celu wstrząśnięcie opinią publiczną, by przez nią wpłynąć na MEN.

W dyskursie związanym z edukacją osób z niepełnosprawnościami obserwujemy także przesunięcia semantyczne w znaczeniach kontekstowych wyrazu: specjalny. Chociaż leksem specjalny w polszczyźnie posiada dwa podstawowe znaczenia: 1. 'odnoszący się, należący do jednego wybranego przedmiotu, zagadnienia, jednej osoby, rzecz; charakterystyczny, przeznaczony wyłącznie dla kogo lub czego; osobny, szczególny'; 2. daw. 'wyjątkowo dobry, doskonały, wyborny, wyśmienity'. W dokumentach związanych z procesem edukacji wyraz specjalny określa pewne antypody edukacji w opozycji do określeń typowy, normalny: ksztatcenie specjalne; specjalne potrzeby edukacyjne, specjalna organizacja nauki oraz metod pracy. W kontekst właczenia - wykluczenia należy więc wpisać nazwy placówek: przedszkola specjalne i szkoty specjalne niejako w opozycji do przedszkoli ogólnodostępnych (x2) i szkót ogólnodostępnych. Wbrew stereotypom i wykluczeniu mają działać przedszkola i szkoty integracyjne i w jakimś sensie szkoty ogólnodostępne $z$ oddziałami specjalnymi, choć struktura językowa nazwy tej ostatniej wykluczeniu nie przeciwdziała. 
Do komunikacyjnych zachowań nieetycznych stojących w sprzeczności z zasadą kooperacji należą: przemilczanie niewygodnych treści przez opuszczenie, niezabieganie o nagłośnienie, ale też publikowanie w miejscach o słabszym zasięgu społecznym, odwracanie uwagi odbiorców i koncentracja na elementach, tematach zastępczych. Milczenie i brak wyraźnych rozwiązań, a także nieprecyzyjne przepisy to podstawowe zarzuty pod adresem MEN w zakresie komunikacyjnych zachowań nieetycznych w związku z indywidualnym kształceniem uczniów z niepełnosprawnościami: Rodzice chca zmiany nieludzkich przepisów. MEN milczy; Minister Zalewska nie wyszła do zebranych; Ministerstwo chowa głowe w piasek, udaje, ze nie ma problemu. Świadczy o tym także fakt, że po wprowadzeniu przepisów w sierpniu 2017 roku, MEN dopiero w lipcu 2018 roku, tuż przed rozpoczęciem roku szkolnego, i to dopiero na skutek interwencji Rzecznika Praw Obywatelskich, zapowiedziało, że $w$ sierpniu kuratorzy będa się spotykać z dyrektorami szkót, by rozmawiać z nimi o edukacji dzieci z orzeczeniami o potrzebie ksztatcenia specjalnego. Ponadto odpowiedzi-komentarze Rzecznika Prasowego MEN Anny Ostrowskiej przemilczają lub osłabiają wydźwięk artykułów prasowych poprzez skracanie i modyfikację tytułów. I tak tytuł artykułu zamieszczonego w serwisie medexpress.pl 27 Mama chłopca chorego na SMA: jestem załamana został skrócony o element emocjonalny do formy Mama chłopca chorego na SMA..., podobnie dwuczłonowy tytuł z „Gazety Wyborczej” Matka walczy o Tomka. Bo „dobra zmiana” zabrała mu szkote, która trzymała go przy życiu uzyskuje postać Matka walczy o szkote dla Tomka..., z kolei tytuł artykułu MEN wyrzuca dzieci niepetnosprawne ze szkół opublikowanego w dzienniku „Fakt” został zmodyfikowany do postaci MEN wyrzuca dzieci ze szkót. Modyfikowanie tytułów, opuszczanie w nich elementów perswazyjnych, odwołujących się do emocji, czasem wyraźnie napastliwych czy ironicznych względem rządzących, jest charakterystycznym zabiegiem osłabiania, tonowania i przemilczania pewnych aspektów wypowiedzi medialnych. Jeśli dodamy do tego wielokrotnie powtarzane w tekstach MEN sformułowania: niepotrzebne emocje, tego typu sytuacje, widzimy cechy języka dyplomacji - z jednej strony tonujące emocje, z drugiej przez ogólnikowość i formuliczność - marginalizujące apele społeczne. $\mathrm{W}$ rozpoczętym przez petycję i szereg artykułów prasowych oraz wiadomości portali internetowych ożywionym dyskursie na temat edukacji uczniów niepełnosprawnych narracja wyraźnie określa dwie strony konfliktu - MEN i rodziców dzieci niepełnosprawnych. Mowa jest o nieludzkich przepisach, niejasnych przepisach, rozporzadzeniu, które wyklucza uczniów niepetnosprawnych, rozporzadzeniu, które ograniczyty dostęp do nauczania indywidualnego na terenie szkoty, przepisy przygotowane przez 
MEN sa tak niejasne, że szkoty moga sie $w$ nich gubić, i że rodzice dzieci niepełnosprawnych walcza o zmiane rozporzadzeń.

W kontekście petycji proszącej o doprecyzowanie przepisów, wątpliwości natury etycznej budzą realizowane przez dokumenty MEN strategie wyraźnie przenoszące odpowiedzialność i zmieniające strony konfliktu, a także - zaryzykujmy stwierdzenie - antagonizujące środowisko rodziców dzieci z niepełnosprawnościami i placówki szkolne wraz z dyrekcją i nauczycielami. W odniesieniu do własnego podmiotu MEN najczęściej używa form czasownikowych lub rzeczowników odsłownych typu: zapewniać, gwarantować, udostępniać, zadbać, przygotować, uruchomić, wspierać, ofiarowywanie, udostępnianie. Nie brak także rzeczowników typu: troska i wsparcie. Czytamy także, że MEN zapewnito takie rozwiazania prawne, które gwarantuja, daja szereg możliwości; Ministerstwo Edukacji Narodowej wspiera uczniów ze specjalnymi potrzebami edukacyjnymi; Chcemy jasno powiedzieć rodzicom, że jesteśmy po ich stronie. Będziemy pilnować tego, żeby te rozwiazania, które sa wprowadzane, byty dobrze realizowane $w$ szkołach - powiedziała wiceminister edukacji. Poprzez swoje dokumenty MEN na nowo definiuje strony opozycyjne w dyskursie o edukacji uczniów z niepełnosprawnościami, wyraźnie wskazując, że MEN jest sprzymierzeńcem rodziców dzieci niepełnosprawnych, ustanawiając w opozycji do rodziców szkołę. Wszak to szkoła, dyrektor szkoły wraz z nauczycielami, zespół nauczycieli i specjalistów mają względem uczniów niepełnosprawnych obowiązek i zobowiązanie wyrażane przez sformułowania typu: szkoła ma obowiazek; zobowiazanie; musi wspótpracować z rodzicem; ma obowiazek zapewnić; musi, powinna opracować program; dyrektor organizuje itp. $\mathrm{Z}$ kolei rodzice $\mathrm{w}$ podobnym tonie dyrektywnym obligowani są do tego, że powinni zgłosić się, powinni pamiętać oraz musza mieć wpływ na edukacje, musza uzyskać kompletna $i$ rzetelna informacje; powinni zostać poinformowani, a ostatecznie maja natychmiast zgłosić się do kuratora, maja obowiazek interweniować, aby dyrektor szkoły realizowat natożone na niego obowiazki.

W zakresie tak widzianych ról uczestników dyskursu teksty MEN ze stylu dyplomacji przechodzą do typowej urzędowej narracji o charakterze dyrektywnym.

\section{WNIOSKI}

Wśród postulatów etycznych prowadzenia dyskusji publicznej zwykle podnosi się równe możliwości czasowe i formalne dla przedstawienia swoich postulatów i krytyki. W dyskursie publicznym prowadzonym między stroną 
rządzącą, reprezentowaną przez ministra, ministerstwo, urzędy a pojedynczymi obywatelami, czasem zrzeszającymi się przy wspólnych inicjatywach (reprezentowanych pośrednio przez niektóre media), postulat ten jest z pewnościa trudny do zrealizowania. Jest to widoczne na poziomie języka i stylu, gdy urząd w ramach odmiany stylowej formułuje dyrektywy, konstruuje zasady, a obywatel wnioski i petycje. Inaczej rozumiane są także obowiązki poszczególnych podmiotów prawnych w zakresie organizowania edukacji osób niepełnosprawnych, które uruchamiane są przez inne strategie opisujące konflikt na łamach prasy, inne w tekstach MEN. Łamanie standardów etycznych w języku mediów przejawia się w sięganiu po retoryczne narzędzia agitacji i odwoływanie się do negatywnych emocji odbiorców. Z kolei teksty ministerialne najczęściej przemilczają niewygodne dla siebie treści, posługują się ogólnikami i formułami, które nie odpowiadają wprost na postulaty, a niejednokrotnie marginalizują, umniejszają ich znaczenie.

Wyraźnie jednak widać, że przedmiot dyskursu silnie wpływa na użycie języka w zakresie strategii nominacyjnych. Jedna i druga strona dyskursu związana jest poprawnością polityczną i pragnieniem języka etycznego, niestygmatyzującego podmiot wypowiedzi (uczniów z niepełnosprawnościami), oraz dążnością do precyzji językowej (bliskiej językowi prawnemu). Wciąż jednak, mimo wyraźnie manifestowanej potrzeby budowania języka etycznego opisującego rzeczywistość niepełnosprawnych, tkwimy w dychotomicznym uniwersum podziałów i nierówności, pomiędzy włączeniem we wspólnotę i wykluczeniem społecznym.

\section{LITERATURA PODMIOTU}

BALINOWSKI P.: „Pozwólcie dzieciom niepełnosprawnym na naukę w szkole”. 40 tys. podpisów podpetycją, https://www.rmf24.pl/fakty/polska/news-pozwolcie-dzieciom-niepelnosprawnym na-nauke-w-szkole-40-tys,nId,2624487, 29 sierpnia 2018 r. [dostęp: 17.09.2018].

BuKŁaHA Z.: Czy 9 tys. uczniów z niepełnosprawnością zostanie wykluczonych ze szkół w Warszawie?, http://warszawa.wyborcza.pl/warszawa/7,54420,23 839901,zeby-szkola-ni kogo-nie-wykluczala.html, 30 sierpnia 2018 r. [dostęp: 17.09.2018].

GMITEREK-ZABŁOCKA A.: „Nikt nie wie, co będzie 1 IX” - rodzice niepełnosprawnych dzieci bija na alarm, http://www.tokfm.pl/Tokfm/7, 130517,23731535,dzieci-z-niepelnosprawnos ciami-marsz-do-domu-rodzice-nie-wiedza.html, 29 lipca 2018 r. [dostęp: 17.09.2018].

https://mimowszystko.org/aktualnosci/podpisz-petycje-o-niewykluczaniu/ [dostęp: 29.08.2018]. https://naszademokracja.pl/petitions/pozwolcie-dzieciom-niepelnosprawnym-z-nauczaniem-indy widualnym-uczyc-sie-w-szkole-1 [dostęp: 29.08.2018]. 
Komentarz MEN do artykułu „MEN wyrzuca dzieci ze szkół”, opublikowanego w dzienniku „Fakt”, 17 maja br., https://www.gov.pl/web/edukacja/wyjasnienia-dla-mediow [dostęp: 29.08.2018].

Komentarz MEN do artykułu pt. „Mama chłopca chorego na SMA...”, opublikowanego w serwisie medexpress.pl 27 kwietna 2018 r., https://www.gov.pl/web/edukacja/wyjasnienia-dlamediow [dostęp: 29.08.2018].

Komentarz MEN do artykułu pt. „Minister obiecuje pomóc Tomkowi”, opublikowanego w dzienniku Fakt, autorstwa MJ, 21 maja 2018 r., https://www.gov.pl/web/edukacja/wyja snienia-dla-mediow [dostęp: 29.08.2018].

Odpowiedź MEN na apel zamieszczony w „Gazecie Wyborczej” 20 czerwca 2018 r. [dostęp: 29.08.2018].

Odpowiedź MEN na artykuł „Matka walczy o szkołę dla Tomka”, opublikowany w „Gazecie Wyborczej” Łódź 13 lipca 2018 r., https://www.gov.pl/web/ edukacja/wyjasnienia-dla-mediow [dostęp: 29.08.2018].

PuCuŁEK A.: Matka walczy o Tomka. Bo „dobra zmiana” zabrała mu szkołę, która trzymała go przy życiu, http://lodz.wyborcza.pl/lodz/7,44788, 23658011,szkola-trzyma-przy-zyciu. html, 13 lipca 2018 r. [dostęp: 17.09.2018].

SZEWCZYK P.: Pomóżcie dzieciom z niepełnosprawnościami uczyć się w szkole, a ich rodzicom i opiekunom kontynuować w tym czasie pracę, http://www. wysokieobcasy.pl/wysokieobcasy/7,163229,23575270,jak-wytlumaczyc-doroslemu-dziecku-po-11-latach-nauki-w-szkole. html?disableRedirects=true, 21 czerwca 2018 r. [dostęp: 17.09.2018].

ŚWIĘCHOWICZ M.: Rodzice niepełnosprawnych dzieci apelują: Pozwólmy wszystkim dzieciom chodzić do szkoły!, http://www.newsweek.pl/polska/ spoleczenstwo/uczniowie-z-niepelno sprawnosciami-w-polskiej-szkole-segregacja-zamiast-integracji,artykuly,431986,1.html, 27 sierpnia 2018 r. [dostęp: 17.09.2018].

\section{LITERATURA PRZEDMIOTU}

BŁACHOwiCz E.: Plotka: w świetle teorii aktów mowy i zasad etyki komunikacji międzyludzkiej, Rzeszów: Wydawnictwo Uniwersytetu Rzeszowskiego 2010.

BRALCZYK J.: O języku polskiej propagandy politycznej lat siedemdziesiątych, Warszawa: Wydawnictwo Trio 2007.

BUGAJSKI M.: Etyka, etykieta, kultura języka, „Poznańskie Spotkania Językoznawcze” 2012, t. 24 , s. $7-21$

DĄBRowsKa A.: Eufemizmy życia codziennego, (Język a kultura, t. 2: Zagadnienia leksykalne i aksjologiczne, red. J. Puzynina, J. Bartmiński), Wrocław: Uniwersytet Wrocławski 1991, s. $163-180$

Etyczne konteksty komunikowania społecznego a bezpieczeństwo personalne i zbiorowe, red. W.J. Maliszewski, K. Czermiński, Toruń: Wydawnictwo Adam Marszałek 2011.

Jankowiak L.A.: Słownictwo medyczne Stefana Falimirza, t. 1: Poczatki polskiej renesansowej terminologii medycznej, Warszawa: Slawistyczny Ośrodek Wydawniczy 2005.

JASTRZĘBSKI J.: Ideologia i komunikacja: o edukacji, pedagogice i mediach, Wrocław: Wydawnictwo Uniwersytetu Wrocławskiego 2011.

KLemensiewiCz Z.: Higiena językowego obcowania, „Język Polski” 45(1965), z. 1, s. 1-8.

KochAN M.: „Przyklejanie etykietek”, czyli o negatywnym określaniu przeciwnika, (Język a kultura, t. 11: Język polityki a współczesna kultura polityczna, red. J. Anusiewicz, B. Siciński), Wrocław: Towarzystwo Przyjaciół Polonistyki Wrocławskiej 1994, s. 85-89. 
MARCJANIK M.: Miejsce etykiety językowej wśród wartości. Uwagi ogólne, (Język a kultura, t. 3: Wartości w języku i tekście, red. J. Puzynina, J. Anusiewicz), Wrocław: Uniwersytet Wrocławski 1991, s. 61-65.

MALISZEWSKI B.: Metafora i aksjologia: wzorzec człowieka w renesansowej literaturze parenetycznej, Lublin: Wydawnictwo UMCS 2009.

PUZYNINA J., PAJDZIŃSKA A.: Etyka słowa, w: O zagrożeniach i bogactwie polszczyzny, red. J. Miodek, Wrocław: Towarzystwo Przyjaciół Polonistyki Wrocławskiej 1996, s. 35-45.

PUZYNINA J.: O warunkach udanej komunikacji językowej, w: Etyka międzyludzkiej komunikacji, red. J. Puzynina, Warszawa: Wydawnictwo Semper 1993, s. 21-23.

WOJCIECHOWSKI E.: O logice przymiotników, „Kwartalnik Filozoficzny” 43(2015), z. 1, s. 15-33.

\author{
STRATEGIE NOMINACYJNE I NARRACYJNE \\ JAKO ŚWIADECTWO ZACHOWAŃ ETYCZNYCH \\ W DYSKURSIE ZWIAZZANYM Z ORGANIZOWANIEM EDUKACJI \\ OSÓB Z NIEPEŁNOSPRAWNOŚCIAMI
}

St res z c z e n i e

Artykuł podejmuje próbę opisu elementów językowych, w ich aspekcie etycznym, obecnych w dyskursie publicznym na temat indywidualnej edukacji uczniów niepełnosprawnych. W obrębie analizowanego dyskursu interesują nas przede wszystkim strategie nominacyjne osób z niepełnosprawnościami i ich opiekunów oraz strategie narracyjne związane z osobami z niepełnosprawnościami, rozpięte dwubiegunowo pomiędzy leksemami właczenie - wykluczenie odnoszące się do uczestników dyskursu: Ministerstwa Edukacji Narodowej, szkoły i reprezentującego ją dyrektora oraz nauczycieli, a także rodziców i dzieci. Elementy nominacyjne w postaci konstrukcji z przymiotnikami atrybutywnymi określające dzieci i młodzież z niepełnosprawnościami pełnią funkcję peryfraz o funkcji eufemizacyjnej, są pod względem znaczeniowym próbą ucieczki przed stygmatyzacją społeczną. Z kolei strategie narracyjne wyraźnie jawią się jako narzędzie sterowania odpowiedzialnością za proces edukacyjny.

Słowa kluczowe: dyskurs publiczny; etyka; język urzędowy; peryfraza; poprawność polityczna.

\title{
NOMINATION AND NARRATIVE STRATEGIES AS A TESTIMONY TO ETHICAL BEHAVIORS IN THE DISCOURSE RELATED TO ORGANIZING THE EDUCATION OF PEOPLE WITH DISABILITIES
}

$$
\text { S u m m a r y }
$$

This article attempts to describe linguistic elements, in their ethical aspect, present in the public discourse on individual education of students with disabilities. 
Within the analyzed discourse, we are primarily interested in the nomination strategies of people with disabilities and their care-takers and narrative strategies related to people with disabilities, bipolarly stretched between lexes inclusion - exclusion and referring to the participants of the discourse: the Ministry of National Education, the school and the principal and teachers representing it, as well as parents and children. Nomination elements with attributes defining children and youth with disabilities play the role of periphasis with a euphemistic function, they are, in terms of meaning, an attempt to escape social stigmatization. In turn, predictive and narrative strategies clearly appear as a tool to control responsibility for the educational process.

Key words: public discourse; ethics; official/administrative language; periphasis; political correctness. 